\title{
Faktor-Faktor Yang Mempengaruhi Pemahaman Pelaku Umkm Terhadap SAK EMKM : Survey Pada UMKM Yang Terdaftar Di Dinas Koperasi Dan Ukm Kota Pekanbaru
}

\author{
INTAN ADINO \\ Universitas Lancang Kuning Pekanbaru \\ Jln. Yos Sudarso KM 08 Rumbai Telp. (0761) 52581 \\ E-mail : intanadino@unilak.ac.id
}

\begin{abstract}
This study was conducted at the Department of Cooperatives and SMEs Pekanbaru City, aims to determine the factors that impact the understanding about SAK EMKM. The factors consists of: SAK EMKM's socialization, educational background, firm's scale and firm's age. The population in this study are all MSMEs that have IUMK at the Department of Coopeartives and SMEs Pekanbaru City which amount 1.102 units, and the number of samples obtained is 92 units using Slovin Formula and the method of selecting samples is incidental sampling. This study using primary data by questionaires and using multiple regression analysis. The results of analysis found that SAK EMKM's socialization and educational background have positive impact to understanding of SMEs businessman about SAK EMKM, but firm's scale and firm's age have no impact to understanding of SMEs businessman about SAK EMKM.
\end{abstract}

Keywords: SAK EMKM's socialization, educational background, firm's scale, firm's age, SAK EMKM

Standar Akuntansi Keuangan Entitas Mikro Kecil dan Menengah (SAK EMKM) telah disahkan oleh Dewan Standar Akuntansi Keuangan - Ikatan Akuntan Indonesia (DSAK - IAI) pada tanggal 24 Oktober 2016 dan mulai diberlakukan secara efektif per 1 Januari 2018. SAK EMKM ini disusun lebih sederhana dibandingkan SAK ETAP dikarenakan banyaknya pelaku UMKM yang belum mampu menyusun laporan keuangan sesuai dengan SAK yang berlaku (Www.goukm.id, 2018). SAK EMKM ditujukan untuk dapat digunakan oleh entitas yang tidak atau belum mampu memenuhi persyaratan akuntansi yang diatur dalam SAK ETAP dan perbedaan utama pada standar ini terdapat pada jumlah laporan keuangan yang harus diterbitkan lebih sedikit yaitu hanya laporan posisi keuangan, laporan laba rugi dan catatan atas laporan keuangan.

SAK EMKM diharapkan dapat memberi dorongan kepada pelaku UMKM agar dapat berkontribusi secara signifikan dalam penerapan pembuatan laporan keuangan. Laporan keuangan merupakan hal yang penting dalam sebuah usaha. Dalam proses pengembangan usaha dan untuk mencapai keberhasilan, tidak hanya modal saja tetapi informasi keuangan dalam catatan akuntansi juga sangatlah penting bagi UMKM (Pinasti, 2007). Pemerintah telah menetapkan sebuah peraturan yang mewajibkan usaha kecil untuk melakukan pencatatan akuntansi yang baik yaitu Peraturan Pemerintah Republik Indonesia Nomor 17 Tahun 2013 tentang pelaksanaan UndangUndang Nomor 20 Tahun 2008 tentang Usaha Mikro, Kecil dan Menengah. Selain berguna untuk mendapatkan kredit dari bank, laporan keuangan juga dapat digunakan untuk perhitungan biaya produksi, mengevaluasi kinerja, mengetahui posisi keuangan, pengambilan keputusan, mengontrol biaya, meningkatkan produktivitas dan masih banyak manfaat yang lainnya.

Meskipun peraturan pencatatan akuntansi telah jelas adanya, namun pada kenyataannya masih banyak pelaku UMKM yang tidak membuat pembukuan 
akuntansi yang sesuai dengan standar. Praktik akuntansi keuangan pada UMKM masih rendah dan memiliki banyak kelemahan (Suhairi, 2004). Penelitian sebelumnya oleh (Salmiah, Satria Tri Nanda, 2018) yang dilakukan terhadap pelaku UMKM yang terdaftar pada Dinas Koperasi Kota Pekanbaru menemukan bahwa tingkat pemahaman pelaku UMKM di Pekanbaru terhadap SAK EMKM masih dalam tingkat cukup. Hal ini mengindikasikan bahwa sebagian besar pelaku UMKM tidak mengetahui dan memahami mengenai SAK EMKM dan penerapannya.

Beberapa penelitian sebelumnya telah dilakukan untuk melihat faktor-faktor apa yang mempengaruhi pemahaman pelaku UMKM terhadap SAK ETAP dan penerapannya. Menurut Susanto (2014) pemahaman terkait SAK ETAP tersebut erat kaitannya dengan proses pemberian informasi dan sosialisasi. Apabila pengusaha mendapatkan informasi dan sosialisasi dengan baik, maka pemahaman mereka terkait SAK ETAP akan menjadi lebih baik dan mendukung proses implementasi SAK ETAP. Selain itu pemahaman tentang SAK ETAP juga dipengaruhi tingkat pendidikan dari pemilik UMKM. Pemilik adalah orang yang memiliki bisnis, yang menanamkan uang dan juga menjalankannya, karena itu mereka mengharapkan adanya pendapatan dalam bentuk keuntungan dari bisnis tersebut. Semakin tinggi pendidikan pemilik, maka pemahaman mengenai bisnis juga semakin baik.

Selain sosialisasi SAK ETAP dan tingkat pendidikan dari pelaku UMKM, skala usaha dan umur usaha juga mempunyai pengaruh terhadap pemahaman SAK ETAP. Skala usaha merupakan ukuran perusahaan yang dapat dilihat dari jumlah karyawan, aset perusahaan, dan penjualan perusahaan. Penelitian Gray (2006) menyatakan ukuran usaha yang besar berimplikasi mempunyai sumber daya yang lebih besar dan juga lebih mampu mempekerjakan karyawan dengan keahlian yang lebih baik, sehingga dapat berpengaruh terhadap implementasi SAK ETAP. Umur perusahaan merupakan lamanya perusahaan telah menjalankan operasionalnya. Holmes \& Nicholls (1988) menyatakan bahwa penyediaan informasi akuntansi dipengaruhi oleh umur perusahaan.

Penelitian ini bertujuan untuk melihat apakah faktor-faktor yang mempengaruhi pemahaman SAK ETAP seperti uraian diatas, juga berpengaruh terhadap pemahaman SAK EMKM. Dengan demikian penelitian ini berjudul "Faktor-faktor yang Mempengaruhi Pemahaman SAK EMKM; Survey pada pelaku UMKM pada Dinas Koperasi Kota Pekanbaru".

Teori ini dikembangkan oleh Venkatesh, Morris, Davis, \& Davis (2003), dirumuskan dengan empat macam penentu inti (core determinant) suatu niat dan pengguna teknologi informasi dengan empat moderator dari hubungan pokok (key relationships). Pertama, ekspektasi terhadap kinerja (performance expectancy), yaitu sejauh mana suatu individu percaya bahwa menggunakan sistem akan membantunya untuk mencapai hasil-hasil dalam kinerja pekerjaannya. Kedua, ekspektasi terhadap upaya (effort expectancy), yaitu sejauhmana tingkat kemudahan yang terkait dengan penggunaan dari sistem. Ketiga, pengaruh sosial (social influence), yaitu sejauh mana persepsi suatu individu akan keyakinan orang lain dalam menggunakan sistem baru. Keempat, kondisi yang mendukung (facilitating condition), yaitu sejauhmana suatu individu percaya bahwa infrastruktur organisasi dan teknis harus ada untuk mendukung penggunaan sistem.

Implikasi teori ini dalam penelitian ini adalah faktor penentu yang ketiga yaitu pengaruh sosial (social influence) dan keempat yaitu kondisi yang mendukung (facilitating condition). Faktor penentu yang ketiga digunakan sebagai landasan teori untuk memperkuat 
kerangka berfikir sosialisasi SAK EMKM berpengaruh terhadap implementasi SAK EMKM karena sosialisasi yang diterima pelaku UMKM merupakan pengaruh sosial yang dapat mempengaruhi persepsi pemilik UMKM untuk menerapkan SAK EMKM. Sedangkan faktor penentu keempat digunakan sebagai landasan teori skala usaha berpengaruh terhadap implementasi SAK EMKM, karena skala usaha yang besar berasumsi bahwa perusahaan mempunyai fasilitas yang mendukung seperti dapat mempekerjakan karyawan dengan keahlian khusus.

Human Capital Theory adalah suatu pemikiran yang menganggap bahwa manusia merupakan suatu bentuk kapital atau barang modal sebagaimana barangbarang modal lainnya, seperti tanah, gedung, mesin, dan sebagainya. Human capital dapat didefinisikan sebagai jumlah total dari pengetahuan, skill, dan kecerdasan rakyat dari suatu negara.

Implikasi Human Capital Theory dalam penelitian ini adalah teori ini digunakan sebagai landasan teori untuk menjelaskan bagaimana tingkat pendidikan pelaku UMKM dan umur usaha dapat berpengaruh terhadap implementasi SAK EMKM.

Sosialisasi SAK EMKM yaitu sosialisasi yang didapatkan oleh pelaku UMKM mengenai SAK EMKM yang merupakan usaha yang dilakukan oleh pihak-pihak terkait yang dapat memberikan sosialisasi SAK EMKM seperti Dinas Koperasi dan UMKM, Ikatan Akuntan Indonesia (IAI), atau lembaga lainnya (Rudiantoro \& Siregar, 2012)

Berdasarkan UU No. 20 tahun 2003 tentang Sistem Pendidikan Nasional, jalur pendidikan terdiri atas pendidikan formal, nonformal, dan informal yang dapat saling melengkapi dan memperkaya. Jenjang pendidikan formal terdiri atas pendidikan dasar, pendidikan menengah, dan pendidikan tinggi. Pendidikan nonformal meliputi pendidikan kecakapan hidup, pendidikan anak usia dini, pendidikan kepemudaan, pendidikan pemberdayaan perempuan, pendidikan keaksaraan, pendidikan keterampilan dan pelatihan kerja, pendidikan kesetaraan, serta pendidikan lain yang ditujukan untuk mengembangkan kemampuan peserta didik. Pendidikan informal merupakan kegiatan belajar secara mandiri yang dilakukan oleh keluarga dan lingkungan.

Menurut Holmes \& Nicholls (1988), ukuran usaha merupakan kemampuan perusahaan dalam mengelola usahanya dengan melihat berapa jumlah karyawan yang dipekerjakan dan besar pendapatan yang diperoleh perusahaan dalam satu periode akuntansi.

Umur usaha adalah lamanya sebuah perusahaan berdiri, berkembang dan bertahan.

SAK EMKM dimaksudkan untuk digunakan oleh entitas mikro, kecil, dan menengah. (DSAK : 2016 : 1 Par 1.1). Entitas mikro, kecil, dan menengah adalah entitas tanpa akuntabilitas publik yang signifikan, sebagaimana didefinisikan dalam Standar Akuntansi Keuangan Entitas Tanpa Akuntabilitas Publik (SAK ETAP), yang memenuhi definisi dan kriteria usaha mikro, kecil, dan menengah sebagaimana diatur dalam peraturan perundang-undangan yang berlaku di Indonesia, setidak-tidaknya selama 2 tahun berturut-turut (DSAK : 2016 : 1 Par 1.2) (IAI, 2016).

Informasi posisi keuangan entitas terdiri dari informasi mengenai asset, liabilitas, dan ekuitas entitas pada tanggal tertentu, dan disajikan dalam laporan keuangan (DSAK : 2016 : 2 Par 2.2).

Informasi kinerja keuangan entitas terdiri dari informasi mengenai penghasilan dan beban selama periode pelaporan, dan disajikan dalam laporan laba rugi (DSAK : 2016 : 2 Par 2.8).

Pengakuan unsur laporan keuangan merupakan proses pembentukan suatu pos dalam laporan posisi keuangan atau laporan laba rugi yang memenuhi definisi suatu unsur sebagaimana diuraikan dalam paragraph 2.1 dan 2.8 
dan memenuhi kriteria sebagai berikut (DSAK : 2016 : 2 Par 2.12) :

(a) Manfaat ekonomik yang terkait dengan pos tersebut dapat dipastikan akan mengalir kedalam atau keluar dari entitas dan

(b) Pos tersebut memiliki biaya yang dapat diukur dengan andal.

Pengukuran adalah proses penetapan jumlah uang untuk mengakui asset, liabilitas, penghasilan, dan beban di dalam laporan keuangan (DSAK : $2016: 2$ Par 2.15). Dasar pengukuran unsur laporan keuangan dalam SAK EMKM adalah biaya historis (DSAK : 2016 : 2 Par 2.16).

\section{PENGEMBANGAN HIPOTESIS}

$\mathrm{H}_{\mathrm{A} 1}$ : Pemberian sosialisasi SAK EMKM berpengaruh positif terhadap pemahaman SAK EMKM.

$\mathrm{H}_{\mathrm{A} 2}$ : Tingkat pendidikan berpengaruh positif terhadap pemahaman SAK EMKM.

$\mathrm{H}_{\mathrm{A} 3}$ : Skala usaha berpengaruh positif terhadap pemahaman SAK EMKM.

$\mathrm{H}_{\mathrm{A} 4}$ : Umur usaha berpengaruh negatif terhadap pemahaman SAK EMKM.

$\mathrm{H}_{\mathrm{A} 5}$ : Sosialisasi SAK EMKM, Tingkat Pendidikan, Skala Usaha dan Umur Usaha secara bersama-sama berpengaruh positif terhadap pemahaman SAK EMKM.

\section{METODE}

Objek penelitian ini adalah pengaruh sosialisasi SAK EMKM, tingkat pendidikan, skala usaha dan umur usaha terhadap pemahaman SAK EMKM bagi pelaku UMKM yang terdaftar pada Dinas Koperasi dan UKM Kota Pekanbaru. Populasi dalam penelitian ini adalah UMKM yang telah memiliki IUMK pada Dinas Koperasi dan UKM Kota Pekanbaru yang berjumlah 1.102 UMKM. Jumlah sampel dalam penelitian ini adalah 92 UMKM. Sumber data primer pada penelitian ini diperoleh langsung dari para pelaku UMKM yang terdaftar pada dinas koperasi kota Pekanbaru. Data ini berupa kuesioner yang telah diisi oleh para pelaku
UMKM yang menjadi responden terpilih dalam penelitian ini.

Teknik analisis data yang digunakan adalah uji instrumen penelitian dan uji hipotesis. Metode statistik yang digunakan adalah teknik regresi berganda dengan menggunakan software SPSS 23.

Hipotesis diuji dengan analisis linear berganda untuk menganalisis pengaruh variabel independen terhadap variabel dependen. Alat pengujian yang digunakan dalam penelitian ini adalah analisis regresi berganda:

$Y=a+b_{1} X_{1}+b_{2} X_{2}+b_{3} X_{3}+b_{4} X_{4}+e$

Keterangan :

$\mathrm{Y}=$ Pemahaman terhadap SAK EMKM

$\mathrm{a}=$ Konstanta

b1, b2= Koefisien regresi

$\mathrm{X}_{1}=$ Sosialisasi SAK EMKM

$\mathrm{X}_{2}=$ Tingkat Pendidikan

$\mathrm{X}_{3}=$ Skala Usaha

$\mathrm{X}_{4}=$ Umur Usaha

$\mathrm{e}=$ Tingkat kesalahan pengganggu

\section{HASIL}

Berdasarkan hasil penelitian dapat diketahui bahwa hasil penelitian uji $\mathrm{t}$, nilai $t_{\text {hitung }}(4,331)>t_{\text {tabel }}(1,98761)$ dan nilai $\operatorname{sig}(0,000)<\alpha(0,05)$, berarti Sosialisasi SAK EMKM $\left(\mathrm{X}_{1}\right)$ berpengaruh signifikan terhadap Pemahaman SAK EMKM (Y) dari pelaku UMKM yang terdaftar pada Dinas Koperasi Kota Pekanbaru.

Kemudian hasil penelitian uji t untuk variabel Tingkat Pendidikan (X2) didapatkan nilai $t_{\text {hitung }}(1,281)>t_{\text {tabel }}$ $(1,98761)$ dan nilai sig $(0,204)>\alpha(0,05)$, berarti Tingkat Pendidikan $\left(\mathrm{X}_{2}\right)$ berpengaruh positif terhadap Pemahaman SAK EMKM (Y) pelaku UMKM yang terdaftar pada Dinas Koperasi Kota Pekanbaru, namun tidak signifikan.

Selanjutnya hasil penelitian uji t untuk variabel Skala Usaha (X3) didapatkan nilai $t_{\text {hitung }}(-0,229)<t_{\text {tabel }}$ $(1,98761)$ dan nilai sig $(0,819)>\alpha(0,05)$, berarti Skala Usaha $\left(\mathrm{X}_{3}\right)$ tidak mempunyai pengaruh terhadap Pemahaman SAK 
EMKM (Y) pelaku UMKM yang terdaftar pada Dinas Koperasi Kota Pekanbaru. Hasil penelitian ini tidak sejalan dengan penelitian Maharani (2013) dan penelitian Mulyaga (2016) yang menemukan pengaruh positif antara skala usaha dengan pemahaman SAK ETAP, dimana semakin besar skala usaha maka semakin tinggi pemahaman terhadap SAK ETAP.

Hasil penelitian uji $\mathrm{t}$ untuk variabel umur usaha $\left(\mathrm{X}_{4}\right)$ didapatkan nilai $\mathrm{t}_{\text {hitung }}$ ($0,991)<t_{\text {tabel }}(1,98761)$ dan nilai sig $(0,325)$ $>\alpha(0,05)$, berarti Umur Usaha $\left(\mathrm{X}_{4}\right)$ tidak memiliki pengaruh terhadap Pemahaman SAK EMKM (Y) pelaku UMKM yang terdaftar pada Dinas Koperasi Kota Pekanbaru.

Terakhir hasil penelitian uji $\mathrm{F}$ diketahui $F_{\text {hitung }}(7,533)>F_{\text {tabel }}(3,10)$ dan sig $(0,000)<\alpha(0,05)$, maka hipotesis yang menyatakan bahwa Faktor-faktor yang mempengaruhi pemahaman SAK EMKM secara simultan berpengaruh signifikan terhadap Pemahaman SAK EMKM dari pelaku UMKM yang terdaftar pada Dinas Koperasi Kota Pekanbaru diterima.

Persamaan regresi yang dihasilkan adalah:

$\mathrm{Y}=2,857+0,331 \mathrm{X}_{1}+0,042 \mathrm{X}_{2}-0,010 \mathrm{X}_{3}-$ $0,049 \mathrm{X}_{4}+\mathrm{e}$

\section{PEMBAHASAN}

\section{Sosialisasi SAK EMKM memiliki pengaruh terhadap Pemahaman pelaku UMKM yang Terdaftar pada Dinas Koperasi Kota Pekanbaru mengenai SAK EMKM.}

Berdasarkan hasil penelitian uji t, nilai $t_{\text {hitung }}(4,331)>t_{\text {tabel }}(1,98761)$ dan nilai $\operatorname{sig}(0,000)<\alpha(0,05)$, berarti Sosialisasi SAK EMKM $\left(\mathrm{X}_{1}\right)$ berpengaruh signifikan terhadap Pemahaman SAK EMKM (Y) dari pelaku UMKM yang terdaftar pada Dinas Koperasi Kota Pekanbaru.

Hasil penelitian ini sejalan dengan penelitian (Susanto, 2014) yang menemukan hasil bahwa pemahaman terkait SAK ETAP erat kaitannya dengan proses pemberian informasi dan sosialisasi. Apabila pengusaha atau pelaku UMKM mendapatkan informasi dan sosialisasi dengan baik, maka pemahaman mereka terkait SAK ETAP akan menjadi lebih baik dan mendukung proses implementasi SAK ETAP. Selain itu hasil penelitian ini juga sejalan dengan hasil penelitian (Mulyaga, 2016) bahwa sosialisasi SAK ETAP juga berpengaruh positif terhadap implementasi SAK ETAP.

Menurut Unified Theory of Acceptance and Use of Technology (UTAUT) menyatakan bahwa penentu pengguna teknologi informasi salah satunya adalah pengaruh sosial (social influnce) yaitu sejauh mana persepsi suatu individu akan keyakinan orang lain dalam menggunakan sistem baru (Venkatesh et al., 2003). Sosialisasi yang diterima pemilik UMKM merupakan pengaruh sosial yang dapat mempengaruhi persepsi pemilik UMKM untuk menerapkan SAK EMKM. Pemberian sosialisasi SAK EMKM yang dilakukan oleh pihak eksternal UMKM, baik Ikatan Akuntan Indonesia (IAI), lembaga pemerintah, lembaga swadaya masyarakat (LSM) atau lembaga lainnya mampu memberikan pemahaman pemilik terkait SAK EMKM dan memberikan pengaruh kepada pemilik UMKM untuk menerapkan SAK EMKM dalam menyusun laporan keuangan perusahaan.

Persamaan regresi yang dihasilkan adalah:

$\mathrm{Y}=2,857+0,331 \mathrm{X}_{1}+0,042 \mathrm{X}_{2}-0,010 \mathrm{X}_{3}$ $-0,049 \mathrm{X}_{4}+\mathrm{e}$

Berdasarkan persamaan regresi di atas, dapat diketahui nilai koefisien regresi variabel $\mathrm{X}_{1}$ sebesar $(0,331)$ artinya adalah setiap peningkatan Sosialisasi SAK EMKM sebesar 1 satuan maka akan meningkatkan Pemahaman Pelaku UMKM yang terdaftar pada Dinas Koperasi Kota Pekanbaru mengenai SAK EMKM sebesar 0,331 dengan asumsi variabel lain tetap.

Dari hasil analisis regresi berganda ditemukan bahwa sosialisasi SAK EMKM akan meningkatkan pemahaman SAK EMKM namun pengaruhnya kecil yaitu 
hanya sebesar 0,331. Jika kita melihat jangka waktu sejak efektif diberlakukan SAK EMKM yaitu 1 Januari 2018 sampai dengan sekarang masih terbilang dalam jangka waktu yang singkat. Sehingga sosialisasi mengenai SAK EMKM belum maksimal dilakukan kepada pelaku UMKM yang terdaftar pada Dinas Koperasi Kota Pekanbaru.

Sosialisasi SAK EMKM merupakan pemberian sosialisasi mengenai SAK EMKM oleh pihak-pihak yang terkait yang dapat memberikan sosialisasi SAK EMKM (seperti: Dinas Koperasi Kota Pekanbaru atau instansi pemerintah) dan juga oleh pihak eksternal seperti lembaga Ikatan Akuntan Indonesia (IAI) atau lembaga lain yang dapat memotivasi pelaku UMKM untuk menerapkan SAK EMKM dalam menyusun laporan keuangan.

Dari hasil analisis statistik deskriptif dapat diketahui bahwa sosialisasi SAK EMKM yang didapat oleh pelaku UMKM yang terdaftar pada Dinas Koperasi Kota pekanbaru, baik melalui sumber media (koran, majalah atau internet), melalui seminar atau pelatihan akuntansi dari instansi pemerintah, lembaga Ikatan Akuntan Indonesia (IAI), Lembaga Swadaya Masyarakat (LSM) atau organisasi lainnya tergolong sangat rendah. Hasil ini menunjukkan bahwa sosialisasi SAK EMKM memang belum banyak dilakukan.

Dengan upaya sosialisasi yang dilakukan dari berbagai sumber seperti media cetak dan media digital, seminar dari berbagi instansi dan lembaga serta pelatihan dengan menghadirkan pembicara yang memahami SAK EMKM diharapkan akan meningkatkan pemahaman pelaku UMKM mengenai SAK EMKM.

Tingkat Pendidikan memiliki pengaruh terhadap Pemahaman Pelaku UMKM yang terdaftar pada Dinas Koperasi Kota Pekanbaru mengenai SAK EMKM.

Berdasarkan hasil penelitian uji $t$ untuk variabel Tingkat Pendidikan (X2) didapatkan nilai $t_{\text {hitung }}(1,281)>t_{\text {tabel }}$ $(1,98761)$ dan nilai sig $(0,204)>\alpha(0,05)$, berarti Tingkat Pendidikan $\left(\mathrm{X}_{2}\right)$ berpengaruh positif terhadap Pemahaman SAK EMKM (Y) pelaku UMKM yang terdaftar pada Dinas Koperasi Kota Pekanbaru, namun tidak signifikan.

Hasil penelitian ini sejalan dengan penelitian Mulyaga (2016) yang menemukan tingkat pendidikan berpengaruh positif terhadap pemahaman SAK ETAP, namun tidak sejalan dengan penelitian Maharani (2013) yang menemukan hasil tingkat pendidikan tidak berpengaruh terhadap pemahaman SAK ETAP.

Menurut Human Capital Theory, pendidikan dapat menanamkan ilmu pengetahuan, ketrampilan, dan nilai-nilai kepada manusia dan karenanya mereka dapat meningkatkan kapasitas belajar dan produktivitasnya. Dengan demikian pendidikan dapat berfungsi meningkatkan produktivitas dan berperan sebagai sinyal kemampuan (Zahro, 2015). Pendidikan formal pemilik dapat berpengaruh terhadap pengetahuan tentang akuntansi, karena materi akuntansi didapatkan pada jenjang pendidikan yang lebih tinggi, pengetahuan akuntansi yang lebih tinggi terutama didapatkan apabila seseorang menempuh pendidikan dengan jurusan akuntansi (Mulyaga, 2016). Menurut (Gray, 2006), pendidikan juga dapat berpengaruh terhadap peningkatkan kemampuan menyerap (termasuk kemampuan akuisisi, asimilasi, transformasi, dan eksploitasi) dari pengetahuan baru.

Persamaan regresi yang dihasilkan adalah:

$\mathrm{Y}=2,857+0,331 \mathrm{X}_{1}+0,042 \mathrm{X}_{2}-0,010 \mathrm{X}_{3}$ $-0,049 \mathrm{X}_{4}+\mathrm{e}$

Berdasarkan persamaan regresi di atas, didapat nilai koefisien regresi variabel $\mathrm{X}_{2}$ sebesar $(0,042)$ artinya adalah setiap peningkatan Tingkat Pendidikan sebesar 1 satuan maka akan meningkatkan Pemahaman Pelaku UMKM yang terdaftar pada Dinas Koperasi Kota Pekanbaru mengenai SAK EMKM sebesar 0,042 dengan asumsi variabel lain tetap.

Dari hasil uji t dan analisis regresi berganda 
menemukan bahwa Tingkat Pendidikan memiliki pengaruh positif terhadap Pemahaman SAK EMKM artinya ketika tingkat pendidikan pelaku UMKM semakin tinggi maka akan meningkatkan pemahaman SAK EMKM tapi pengaruhnya kecil yaitu hanya sebesar 0,042. Hal ini disebabkan karena latar belakang dari tingkat pendidikan yang beragam. Dari hasil analisis statistik deskriptif diketahui bahwa pelaku UMKM yang terdaftar pada Dinas Koperasi Kota Pekanbaru paling banyak mempunyai tingkat pendidikan terakhir SMA. Namun, dari data ini belum diketahui apakah berasal dari latar belakang akuntansi atau non-akuntansi. Dari penelitian Maharani (2013) diketahui bahwa latar belakang pendidikan akuntansi mempunyai pengaruh positif dan signifikan terhadap pemahaman SAK ETAP, namun tingkat pendidikan yang dilihat dari jenjang pendidikan yang sudah ditempuh tidak mempunyai pengaruh terhadap pemahaman SAK ETAP.

Skala Usaha tidak memiliki pengaruh terhadap Pemahaman Pelaku UMKM yang terdaftar pada Dinas Koperasi Kota Pekanbaru mengenai SAK EMKM.

Berdasarkan hasil penelitian uji $\mathrm{t}$ untuk variabel Skala Usaha (X3) didapatkan nilai $t_{\text {hitung }}(-0,229)<t_{\text {tabel }}(1,98761)$ dan nilai sig $(0,819)>\alpha(0,05)$, berarti Skala Usaha $\left(\mathrm{X}_{3}\right)$ tidak mempunyai pengaruh terhadap Pemahaman SAK EMKM (Y) pelaku UMKM yang terdaftar pada Dinas Koperasi Kota Pekanbaru. Hasil penelitian ini tidak sejalan dengan penelitian Maharani (2013) dan penelitian Mulyaga (2016) yang menemukan pengaruh positif antara skala usaha dengan pemahaman SAK ETAP, dimana semakin besar skala usaha maka semakin tinggi pemahaman terhadap SAK ETAP.

Theory of Acceptance and Use of Technology (UTAUT) menjelaskan bahwa adopsi sistem informasi dapat digunakan apabila adanya kondisi yang mendukung (facilitating condition). Skala usaha yang besar berimplikasi perusahaan lebih dapat menyediakan fasilitas yang mendukung. Dari hasil analisis statistik deskriptif diketahui bahwa paling banyak jumlah karyawan dari pelaku UMKM yang terdaftar pada Dinas Koperasi Kota Pekanbaru adalah sebanyak 1-5 orang yaitu sebesar $64 \%$. Hal ini dapat kita golongkan paling banyak termasuk dalam kategori mikro.

Persamaan regresi yang dihasilkan adalah:

$\mathrm{Y}=2,857+0,331 \mathrm{X}_{1}+0,042 \mathrm{X}_{2}-0,010 \mathrm{X}_{3}$ $-0,049 \mathrm{X}_{4}+\mathrm{e}$

Berdasarkan persamaan regresi di atas, didapat nilai koefisien regresi variabel $\mathrm{X}_{3}$ sebesar $(-0,010)$ artinya adalah setiap peningkatan skala usaha sebesar 1 satuan maka akan menurunkan Pemahaman Pelaku UMKM yang terdaftar pada Dinas Koperasi Kota Pekanbaru mengenai SAK EMKM sebesar 0,010 dengan asumsi variabel lain tetap.

Dari hasil uji $\mathrm{t}$ dan analisis regresi berganda ditemukan bahwa Skala Usaha memiliki pengaruh negatif terhadap Pemahaman SAK EMKM artinya ketika skala usaha (yang dilihat dari jumlah karyawan) meningkat, hal ini akan menurunkan pemahaman SAK EMKM. Hal ini dikaitkan lagi dengan sumber daya manusia yang dimiliki oleh UMKM. Semakin bertambah banyaknya jumlah karyawan yang dimiliki oleh UMKM, semakin beragam latar belakang dan tingkat pendidikan yang dimiliki oleh UMKM yang membuat tidak terfokus pada pemahaman SAK EMKM.

Umur usaha tidak memiliki pengaruh terhadap Pemahaman Pelaku UMKM yang terdaftar pada Dinas Koperasi Kota Pekanbaru mengenai SAK EMKM.

Berdasarkan hasil penelitian uji $\mathrm{t}$ untuk variabel umur usaha $\left(\mathrm{X}_{4}\right)$ didapatkan nilai $t_{\text {hitung }}(-0,991)<t_{\text {tabel }}(1,98761)$ dan nilai sig $(0,325)>\alpha(0,05)$, berarti Umur Usaha $\left(\mathrm{X}_{4}\right)$ tidak memiliki pengaruh terhadap Pemahaman SAK EMKM (Y) pelaku UMKM yang terdaftar pada Dinas Koperasi Kota Pekanbaru. Hasil penelitian ini sejalan dengan penelitian Maharani 
(2013) dan Mulyaga (2016) yang juga menemukan bahwa umur usaha tidak berpengaruh terhadap pemahaman SAK ETAP.

Dari persamaan regresi dapat dilihat bahwa:

$\mathrm{Y}=2,857+0,331 \mathrm{X}_{1}+0,042 \mathrm{X}_{2}-0,010 \mathrm{X}_{3}-$ $0,049 \mathrm{X}_{4}+\mathrm{e}$

Berdasarkan persamaan regresi di atas, didapat nilai koefisien regresi variabel $\mathrm{X}_{4}$ sebesar $(-0,049)$ artinya adalah setiap peningkatan umur usaha sebesar 1 satuan maka akan menurunkan Pemahaman Pelaku UMKM yang terdaftar pada Dinas Koperasi Kota Pekanbaru mengenai SAK EMKM sebesar 0,049 dengan asumsi variabel lain tetap.

Beberapa penelitian terdahulu mempunyai hasil penelitian yang berbedabeda, antara lain penelitian Holmes dan Nicholls (1988) menyatakan bahwa umur usaha berpengaruh negatif terhadap penyiapan dan penggunaan informasi akuntansi, perusahaan yang berdiri kurang dari 10 tahun, menyediakan lebih banyak informasi akuntansi statutori, informasi akuntansi anggaran dan informasi akuntansi tambahan yang digunakan dalam pengambilan keputusan, berbeda dengan perusahaan yang berdiri sudah lebih dari 10 tahun. Penelitian ini juga menyatakan bahwa semakin muda umur perusahaan terdapat kecenderungan untuk menyediakan informasi akuntansi yang ekstensif yang berguna dalam pengambilan keputusan. Begitu juga dengan penelitian Rudiantoro dan Siregar (2012). Namun berbeda dengan penelitian Das dan Dey (2005) yang menyatakan bahwa semakin lama umur perusahaan, maka frekuensi melakukan pembukuan akan semakin teratur. Dengan kata lain, umur usaha berpengaruh positif terhadap penerapan akuntansi. Umur usaha yang panjang akan memberikan keuntungan telah mempunyai struktur dan proses yang rutin dalam mendisiplinkan setiap tindakan perusahaan. Di lain sisi, usaha yang baru berdiri akan mendorong pengusaha untuk lebih giat mencari informasi dan cara untuk mengembangkan usaha dengan menyediakan laporan keuangan (Rudiantoro dan Siregar, 2012).

Sehingga penyebab umur usaha tidak berpengaruh terhadap pemahaman SAK EMKM dapat disebabkan oleh beberapa hal, bisa dipengaruhi oleh kepribadian dan motivasi pemilik UMKM (Masitoh dan Widayanti, 2015). Kepribadian adalah keseluruhan sikap, perasaan, ekspresi dan temperamen seseorang, sedangkan motivasi adalah kondisi internal yang membangkitkan seseorang untuk bertindak, mendorong untuk mencapai tujuan tertentu dan membuat seseorang tetap tertarik dalam kegiatan tertentu (Weiner, 1990). Penyebab lain juga dipengaruhi bagaimana persepsi pelaku UMKM terhadap pentingnya laporan keuangan. Persepsi adalah suatu proses dimana individu mengorganisasikan dan menginterpretasikan kesan sensori mereka untuk memberi arti pada lingkungan mereka (Robbins, 2002).

\section{Sosialisasi SAK EMKM, Tingkat Pendidikan, Skala Usaha dan Umur Usaha secara simultan memiliki pengaruh terhadap Pemahaman SAK EMKM dari Pelaku UMKM yang terdaftar pada Dinas Koperasi Kota Pekanbaru.}

Berdasarkan hasil penelitian uji $\mathrm{F}$ diketahui $F_{\text {hitung }}(7,533)>F_{\text {tabel }}(3,10)$ dan sig $(0,000)<\alpha(0,05)$, maka hipotesis yang menyatakan bahwa Faktor-faktor yang mempengaruhi pemahaman SAK EMKM secara simultan berpengaruh signifikan terhadap Pemahaman SAK EMKM dari pelaku UMKM yang terdaftar pada Dinas Koperasi Kota Pekanbaru diterima.

Dari tabel juga diketahui Adjusted $R$ Square sebesar 0,223 yang artinya adalah sumbangan pengaruh variabel independen (Sosialisasi SAK EMKM, Tingkat pendidikan, Skala Usaha dan Umur Usaha) terhadap variabel dependen (Pemahaman SAK EMKM) adalah sebesar 22,3\%, sedangkan sisanya sebesar $77,7 \%$ dipengaruhi oleh variabel lain yang tidak dimasukkan dalam penelitian ini. 
Kecilnya nilai Adjusted $R$ Square $(22,3 \%)$ dapat dijelaskan bahwa banyak faktor yang mempengaruhi pemahaman pelaku UMKM mengenai SAK EMKM, tidak hanya sosialisasi SAK EMKM, tingkat pendidikan, skala usaha dan umur usaha. Kalau dilihat dari Peraturan Pemerintah Republik Indonesia Nomor 17 Tahun 2013 tentang pelaksanaan Undang-Undang Nomor 20 Tahun 2008 tentang Usaha Mikro, Kecil dan Menengah, pemerintah sudah mewajibkan usaha kecil untuk melakukan pencatatan akuntansi yang baik, supaya dapat digunakan untuk mengajukan kredit kepada bank, penghitungan biaya proses produksi, mengevaluasi kinerja, mengetahui posisi keuangan dan pengambilan keputusan. Namun pada kenyataannya masih banyak pelaku UMKM yang tidak membuat pembukuan akuntansi sesuai denagn standar. Jadi bisa dilihat faktor lain yang mempengaruhi yaitu latar belakang pendidikan akuntansi atau non-akuntansi, kepribadian dan motivasi, serta persepsi dari pelaku UMKM tersebut.

\section{SIMPULAN}

Dari hasil penelitian dan pembahasan, penulis dapat membuat kesimpulan dari penelitian ini sebagai berikut :

1. Sosialisasi SAK EMKM memiliki pengaruh terhadap Pemahaman Pelaku UMKM mengenai SAK EMKM. Semakin sering pelaku UMKM mendapat sosialiasi SAK EMKM, maka semakin tinggi tingkat pemahaman pelaku UMKM mengenai SAK EMKM.

2. Tingkat Pendidikan memiliki pengaruh terhadap Pemahaman Pelaku UMKM mengenai SAK EMKM. Semakin tinggi tingkat pendidikan pelaku UMKM, maka semakin tinggi pula pemahaman pelaku UMKM mengenai SAK EMKM.

3. Skala Usaha tidak memiliki pengaruh terhadap Pemahaman Pelaku UMKM mengenai SAK EMKM. Dalam penelitian ini ditemukan hasil bahwa baik perusahaan kecil maupun perusahaan besar tingkat pemahaman pelaku UMKM mengenai SAK EMKM masih dalam tingkat cukup.

4. Umur Usaha tidak memiliki pengaruh terhadap Pemahaman Pelaku UMKM mengenai SAK EMKM. Dalam penelitian ini ditemukan hasil bahwa baik perusahaan yang baru berdiri maupun perusahaan yang sudah lama berdiri tingkat pemahaman pelaku UMKM mengenai SAK EMKM masih dalam tingkat cukup.

5. Sosialisasi SAK EMKM, Tingkat Pendidikan, Skala Usaha dan Umur Usaha secara simultan memiliki pengaruh terhadap Pemahaman Pelaku UMKM mengenai SAK EMKM.

Berdasarkan kesimpulan penelitian maka penulis memberikan saran sebagai berikut :

1. Agar pelaksanaan sosialisasi SAK EMKM dapat ditingkatkan karena akan memiliki pengaruh terhadap pemahaman pelaku UMKM mengenai SAK EMKM.

2. Bagi peneliti selanjutnya yang akan meneliti mengenai faktor-faktor yang mempengaruhi pemahaman pelaku UMKM agar menambah variable lain yang juga diduga memiliki pengaruh terhadap pemahaman SAK EMKM.

\section{DAFTAR RUJUKAN}

Becker, G. S. (1962). Investment in Human Capital: A Theoretical Analysis. Journal of Political Economy. https://doi.org/10.1086/258724

Das, Dey. (2005). Factors that Affect the Perception of Small and Medium Sized-Business (SMEs) Community on the Importance of Financial Statements, the amount of credit 
received and Implementation Prospects. KnE Social Sciences.

Ghozali, I. (2013). Analisis Multivariate dengan program IBSM SPSS21. Semarang: Universitas Diponegoro.

Gray, C. (2006). Absorptive capacity, knowledge management and innovation in entrepreneurial small firms. International Journal of Entrepreneurial Behavior \& Research. https://doi.org/10.1108/1355255061 0710144

Herawati, Edy Suwito, A. (2005). Analisis Pengaruh Karakteristik Perusahaan Terhadap Tindakan Perataan Laba yang Dilakukan oleh Perusahaan yang Terdaftar di Bursa Efek Jakarta. Simposium Nasional Akuntansi XVI.

Holmes, S., \& Nicholls, D. (1988). an Analysis of the Use of Accounting Information By Australian Small Business. Journal of Small Business Management.

IAI. (2016). DSAK IAI. Standar AKuntansi Keuangan Entitas Mikro, Kecil dan Menengah.

Jati. (2004). Menumbuhkan kebiasaan usaha kecil menyusun laporan keuangan. Jurnal Bisnis Dan Usahawan, II, 210-218.

Kamus Besar Bahasa Indonesia. (2007). Kamus Besar Bahasa Indonesia. Pusat Bahasa Departemen Pendidikan Nasional. https://doi.org/10.1017/CBO978110 7415324.004

Kusnia. (2013). Pengaruh umur perusahaan, ukuran perusahaan dan leverage terhadap intellectual capital disclosure. Skripsi Dipublikasikan.

\section{Fakultas Ekonomi Universitas Pasundan, Bandung.}

Maharani. (2013). Faktor-faktor yang Mempengaruhi Pemahaman Usaha Mikro, Kecil dan Menengah dalam Menyusun laporan Keuangan Berdasarkan SAK ETAP. FE Jember Universitas

Muhammadiyah, (2).

Mazanai, M., \& Fatoki, O. (2012). Perceptions of Start-Up Small and Medium-Sized Enterprises (SMEs) on the Importance of Business development Services Providers (BDS) on Improving Access to Finance in South Africa. Journal of Social Science, 30(1), 31-41.

Mulyaga. (2016). Faktor-faktor yang mempengaruhi implementasi standar akuntansi keuangan entitas tanpa akuntabilitas publik. Skripsi Dipublikasikan. Universitas Negri Semarang.

Pemerintah Republik Indonesia. (2003). Undang-Undang Republik Indonesia Nomor 20 Tahun 2003 Tentang Sistem Pendidikan Nasional. Departemen Pendidikan Nasional.

Pinasti, M. (2007). No Title. Simposium Nasional Akuntansi X, 1-21.

Putra, H. A., \& Kurniawati, E. P. (2012). Penyusunan Laporan Keuangan UMKM berdasarkan Standar Akuntansi Keuangan-Entitas Tanpa Akuntabilitas Publik ( SAKETAP ) ( Kasus pada UD . Mebel Novel' 1 di Banyuwangi )., 10(4), 547-580.

Ritcher. (1987). An econometrics analysis of income tax evasion and its detection. RAND Journal of Economics, 22 No. 1, 14-35. 
Rudiantoro, R., \& Siregar, S. V. (2012). Kualitas Laporan Keuangan UMKM serta Prospek Implementasi SAK ETAP. Jurnal Akuntansi Dan Keuangan Indonesia, 9(1), 1-21. https://doi.org/10.21002/jaki.2012.0 1

Rustaman. (2003). Kemampuan dasar bekerja ilmiah dalam sains. Makalah Pada Seminar Pendidikan Biologi. FKIP Unpas, Bandung.

Robbin SP, Judge. (2002). Perilaku Organisasi. Jakarta. Salemba Empat.

Salmiah, Satria Tri Nanda, I. (2018). PEMAHAMAN PELAKU UMKM TERHADAP SAK EMKM : SURVEY PADA UMKM YANG TERDAFTAR DI DINAS KOPERASI DAN UKM KOTA PEKANBARU.

Seftianne, \& Handayani, R. (2011). FaktorFaktor Yang Mempengaruhi Struktur Modal Pada Perusahaan Publik Sektor Manufaktur. Jurnal Bisnis Dan Akuntansi. https://doi.org/10.13140/RG.2.2.306 30.32324

Siswono. (2013). Penerapan penyusunan laporan keuangan pada usaha kecil menengah berbasis entitas tanpa akuntabilitas publik (Studi Kasus UKM Brebes Fried Chicken). Jurnal Ekonomi Fakultas Ekonomi Dan Bisnis Universitas Dian Nuswantoro Semarang.

Solovida. (2003). Analisis faktor-faktor yang mempengaruhi penyiapan dan penggunaan informasi akuntansi pada perusahaan kecil dan menengah.

Sugiyono. (2014). Desain Penelitian. In Metode Penelitian Kuantitatif, Kualitatif dan $R \& D$.
Suhairi. (2004). Personality, Accounting Knowledge, Accounting Information Usage and Performance: a research on enterpreneurship of Indonesia Medium Enterprise.

Susanto, N. Y. (2014). Prospek implementasi SAK ETAP berbasis kualitas laporan keuangan UMKM.

Suwardjono. (2005). Teori Akuntansi: Perekayasaan Pelaporan Keuangan (Edisi III). Yogyakarta, BPFE.

Undang-Undang No. 20 Tahun 2008. (2008). Tentang: Usaha,Mikro,Kecil dan Menengah. Sekretariat Negara. Jakarta.

Venkatesh, V., Morris, M., Davis, G., \& Davis, F. (2003). User Acceptance of Information Technology: Toward a Unified View. MIS Quarterly. https://doi.org/10.2307/30036540

Weiner. (1990). History of Motivational Research in Education. Journal of Educational Psychology Volume. 82 no. 4.

Www.goukm.id. (2018). SAK EMKM, Menilik Standar Akuntansi untuk UMKM rancangan IAI.

Zahro, S. D. W. (2015). Determinan Kebutuhan SAK ETAP bagi UKM (Studi Empiris Pada UKM Makanan di Kota Semarang). Universitas Islam Sultan Agung, 2. 